\title{
PERSONAL EVANGELISATION METHOD (PEM) SEBAGAI POLA PENDEKATAN PEKABARAN INJIL DALAM KONTEKS PLURALISME
}

\author{
Rio Janto Pardede
}

\section{PENDAHULUAN}

Pekabaran Injil merupakan perintah Yesus Kristus yang dipercayakan kepada para murid. Roma 1 :16-17 bahwa, "Injil adalah kekuatan Allah untuk menyelamatkan manusia dari dosa." Dosa mengakibatkan keterpisahan antara Allah dengan manusia, bahkan dosa membuat hidup manusia menjadi terpuruk karena dosa membuat manusia menjadi musuh Allah. Cara yang dilakukan Allah untuk mendamaikan manusia dengan-Nyaadalah dengan mengutus Anak-Nya yaitu Tuhan Yesus Kristus sebagai pendamai sehingga manusia dapat mengalami pemulihan dan pembenaran dari Allah dan berita inilah yang harus dibawa oleh para murid dalam pemberitaan Injil.

Penginjilan adalah rancangan dan karya Allah yang menghimpun bagi diri-Nya suatu umat untuk bersekutu, menyembah dan melayani Dia secara utuh dan serasi. ${ }^{1}$ George W. Peters menegaskan bahwa, "penginjilan merujuk pada tahap awal dari pelayanan kristiani." Karena itulah, penginjilan merupakan pewartaan berwibawa mengenai Injil Yesus Kristus, seperti yang dijelaskan dalam Alkitab. ${ }^{2}$ Dengan kondisi manusia yang berdosa, manusia sangat membutuhkan uluran belas kasihan Tuhan dalam hal keselamatan dirinya sendiri. Untuk itulah sangat perlu pewartaan Injil, seperti pendapat J. I. Packer bahwa, " menginjili berarti menghadirkan Kristus Yesus dalam kuasa Roh Kudus sedemikian rupa sehingga manusia akandatang dan percaya kepada Allah melalui Dia, menerima Dia sebagai Juruselamat dan melayani Dia sebagai Raja didalam persekutuan dengan GerejaNya. ${ }^{3}$ Namun, penginjilan bukan hanya sekedar mewartakan kebenaran tetapi juga harus memiliki motivasi yang benar. Karena itulah, kualifikasi seorang pembawa berita Injil adalah 1) Sudah lahir baru: mengalami pertobatan, 2) Memiliki pemahaman akan firman Tuhan: dimuridkan, 3) Hatinya tergerak karena belas kasihan: memiliki hati Kristus yang berbelas kasihan akan jiwa-jiwa yang terhilang.

1 Yakub Tomatala, Penginjilan Masa Kini 1 (Malang: Gandum Mas, 2004), hal. 2.

2 George W. Peters (A Bilblical Theology Of Missions: Teologia Alkitabiah tentang Pekabaran Injil (Malang: Gandum Mas, 2006), hal. 12. 28.

3 J. I. Packer, Penginjilan dan Kedaulatan Allah (Surabaya: Momentum, 2014), hal. 
Dan ketiga kualifikasi ini saling berkaitan, orang yang mengalami pertobatan secara pribadi akan mendorong dirinya sendiri untuk dapat menjaga spiritualitas melalui pemuridan atau pembelajaran firman Tuhan, yang diaplikasikan dalam kehidupan sehari-hari yaitu dengan memiliki kerinduan untuk bersaksi akan pengalamannya tersebut.

Pada masa kini, gereja dan orang yang "mengaku" percaya Yesus justru bergeser dari Amanat Agung tersebut, gereja melakukan tindakan atau strategistrategi "licik" dalam pengembangan pertumbuhan jemaat, seperti: a) Curi domba: mengambil jemaat gereja lain menjadi jemaatnya sendiri dengan alasan-alasan yang sepertinya "rohani", seperti: itukan dombanya Tuhan jadi terserahlah dia mau kemana, kalau makanan yang kita berikan lebih dari makanan yang diberikan gembalanya kan tidak salah kita jika jemaat tersebut pindah, b) Manipulasi Kebaktian Kebangunan Rohani: dengan membawa publik pigur seperti artis dalam menjaring jiwa. Padahal artis yang dibawapun belum lahir baru, c) Menjual Produk rohani yang dibungkus dengan kebutuhan pokok: tawaran jika datang beribadah maka akan mendapatkan beras, indomie, bahkan dapat uang jika bisa membawa jiwa baru ke gereja, hanya supaya jemaatnya bertambah, bahkan dengan berbagai strategi-strategi licik lainnya.

Gereja dan orang percayapun membuat alasan-alasan klasik untuk tidak mewartakan Injil, seperti: a) Pekabaran Injil bukan tugas jemaat, itu tugas hamba-hamba Tuhan untuk itulah mereka sekolah teologi dan untuk itu juga mereka di "bayar", b) Gereja sudah sibuk dengan persoalan jemaat, jadi sudah tidak sempat memikirkan Pekabaran Injil lagi, c) Gereja takut memberitakan Injil karena takut didemo setelah membawa jiwa baru yang dari non Kristen, d) jemaat tidak dilatih dan tidak tahu caranya dalam menyampaikan Injil, e) takut ditolak karena memberitakan Injil, f) tidak perlu lagi Pekabaran Injil, karena urusan surga atau neraka urusan masing-masing pribadi, g) nanti kalau orang yang diinjili bertanya takut tidak tahu menjawabnya, h) takut kalau nantinya menganggu hubungan persahabatan dengan sahabat yang diinjili dan alasanalasan lainnya.

Bahkan gereja, orang percaya serta hamba-hamba Tuhan memiliki pergumulan sendiri ketika ingin mewartakan Injil kepada orang-orang yang memiliki pemahaman pluralisme agama. Dan sering sekali, gereja, orang percaya dan hamba Tuhan pun tidak bisa berargumen ketika seseorang memiliki pemahaman bahwa semua agama adalah sama, hanya caranya yang berbeda-beda. Karena yang penting adalah hubungan silaturahmi tetap dapat dijalankan dengan baik.

Istilah Pluralisme bukanlah istilah yang asing dalam konteks masyarakat yang menjaga relasi sosial antar umat beragama dan antar agama, demi dapat menjalin kebersamaan dan kerukunan. Pluralisme adalah keadaan masyarakat yang terdiri dari berbagai macam perbedaan; masyarakat 
majemuk. ${ }^{4}$ Pluralisme agama merupakan konsep yang luas tentang penerimaan agama-agama: 1) Tiada satu pun agama yang tunggal dan eksklusif untuk menjadi sumber kebenaran, atau setidak-tidaknya terdapat kebenaran dan nilai yang benar dalam agama lain. 2) Penerimaan kebenaran wujud dalam dua atau lebih agama dengan penekanan aspek-aspek yang diterima oleh agama-agama tersebut. 3) Menggalakkan kerjasama dan dialog antara agama-agama yang berbeza bagi meningkatkan persefahaman. 4) Digunakan sebagai istilah untuk merujuk kepada keadaan hidup bersama secara harmoni di antara penganut agama yang berbeda. ${ }^{5}$ Pluralisme secara substansional termanifestasi dalam sikap untuk saling mengakui sekaligus menghargai, menghormati, memelihara, dan bahkan mengembangkan atau memperkaya keadaan yang bersifat plural, jamak, atau banyak. ${ }^{6}$ Menurut Alwi Shihab, pengertian pluralisme dapat disimpulkan menjadi beberapa bagian yaitu: pertama, pluralisme tidak semata menunjuk pada kenyataan tentang adanya kemajemukan. Namun, yang dimaksud pluralisme adalah keterlibatan aktif terhadap kenyataan kemajemukan tersebut. Kedua, pluralisme harus dibedakan dengan kosmopolitanisme. Dalam hal ini Kosmopolitanisme menunjuk suatu realitas di mana aneka ragam ras dan bangsa hidup berdampingan di suatu lokasi. Maksudnya walaupun suatu ras dan bangsa tersebut hidup berdampingan tetapi tidak ada interksi sosial. Ketiga, konsep pluralisme tidak dapat disamakan dengan relativisme. Paham relativisme menganggap "semua agama adalah sama". Keempat, pluralisme agama bukanlah sinkretisme, yakni menciptakan suatu agama baru dengan memadukan unsur tertentu atau sebagian komponen ajaran dari beberapa agama untuk dijadikan bagian integral dari agama tersebut. ${ }^{7}$ Sementara itu Syamsul Ma'arif mendefinisikan pluralisme adalah suatu sikap saling mengerti, memahami, dan menghormati adanya perbedaanperbedaan demi tercapainya kerukunan antarumat beragama. Dan dalam berinteraksi dengan aneka ragam agama tersebut, umat beragama diharapkan masih memiliki komitmen yang kokoh terhadap agama masingmasing. ${ }^{8}$ Jadi melalui definisi diatas, maka pluralisme agama adalah merupakan sikap untuk membangun kesadaran normatif teologis, namun juga membangun kesadaran sosial, dimana manusia hidup secara berdampingan, walaupun ditengah masyarakat yang berbeda-beda, baik dari segi: agama, etnis, budaya dan berbagai perbedaan lainnya.

4 Em Zul Pajri, Ratu Aprillia Senja, Kamus Lengkap Bahasa Indonesia (Jakarta: Difa Publisger, 2008), hal. 661.

5 https://ms.wikipedia.org/wiki/Pluralisme_agama, di akses tanggal 27 Agustus 2018

6 Ngainun Naim dan Achmad Sauqi, Pendidikan Multikultural Konsep dan Aplikasi, (Jogjakarta: Ar-Ruzz Media, 2008), hlm. 75.

7 Alwi Shihab, Islam Inklusif Menuju Sikap Terbuka, hlm. 41-42. 2005), hlm. 17.

8 Syamsul Ma'arif, Pendidikan Pluralisme di Indonesia, (Jogjakarta: Logung Pustaka, 
Berdasarkan penjelasan istilah pluralisme agama tersebut, bukan berarti gereja atau orang percaya "bungkam" dan tidak lagi mewartakan kabar baik kepada mereka. Namun, inilah realita yang ada saat ini terjadi, hal penting yang harus dikerjakan oleh gereja dan orang percaya adalah mengembalikan pergeseran pemahaman Amanat Agung tersebut kepada jalurnya, bahwa Amanat Agung adalah tanggungjawab yang harus dilaksanakan oleh gereja dan orang percaya. Gereja, orang percaya dan hamba Tuhan harus tetap memiliki hati yang berbelaskasihan, sehingga keluarga, sahabat atau teman, tetangga dan lain-lainnya juga mendengar tentang kabar penyelamatan oleh Injil yang dikerjakan oleh Allah melalui gereja dan orang percaya.

\section{PEMBAHASAN}

Berbagai metode yang ditemukan oleh hamba-hamba Tuhan diladang pelayanan untuk menjawab kebutuhan tentang cara atau teknik pekabaran Injil, yang secara khusus dilakukan dalam penginjilan pribadi. Personal Evangelisation Method (PEM) menjadi salah satu metode untuk menjawab kebutuhan penginjilan dalam konteks pluralisme agama.

\section{A. TujuanMateri}

Tujuan dari penyampaian materi dalam bab ini adalah sebagai berikut.

a) Memberikanpembekalan dan metode praktis dalam Pekabaran Injil.

b) Mempersiapkan orang percaya untuk melaksanakan Amanat Agung Tuhan Yesus Kristus (Mat 28 : $19^{\prime}$ '...Jadikanlah semua bangsa Murid$\mathrm{Ku}$ ').

c) Menolong jemaat dan para hamba-hamba Tuhan dalam menyampaikan berita Injil.

\section{B. Prinsip}

Beberapa prinsip yang menjadi dasar sebelum melakukan pekabaran Injil dalam metode ini, akan diuraiakan sebagai berikut:

\section{a. Doa yang terarah}

Hidup baru, pemahaman akan Firman Tuhan, dan hati yang tergerak karena belas kasihan, tidak akan lengkap jika semua prinsip tersebut tidak didasarkan pada doa yang terarah dan secara terus menerus. Doa akan membantu si pemberita Injil untuk peka terhadap kebutuhan utama si pendengar Injil. Doa akan menjadi senjata seorang pemberita Injil untuk menerobos tembok-tembok penghalang pekabaran Injil, karena perjuangan pemberita Injil bukanlah melawan darah dan daging, melainkan melawan penghulu-penghulu di udara dan penguasa-penguasa dunia yang gelap ini (Efesus 6:10-20). Doa akan menuntun si pemberita untuk peka melihat target mana yang membutuhkan Firman Tuhan yang hidup. Doa juga akan menolong 
si pemberita untuk menerima hikmat dari Roh Kudus sebagai Roh penolong dan penuntun sehingga si pemberita Injil benar-benar mengandalkan Roh Kudus dan bukan mengandalkan metodenya yang luar biasa, kefasihannya berbicara, kemampuan intelektualnya dalam menghafal dan menjawab semua pertanyaan-pertanyaan serangan. Karena kecenderungan orang yang tidak berdoa dan mengandalkan Roh Kudus dalam pemberitaan Injil, akan membuat si pemberita Injil merasa berjasa dalam penyampaian berita Injjil tersebut. Tugas si pemberita Injil hanya menyampaikan apa yang diperintahkan oleh Tuhan Yesus yaitu beritakan Injil, tetapi pertobatan seseorang tidak ditentukan oleh si pemberita melainkan oleh Roh Kudus yang telah mempertemukan dan mengatur waktu serta menjamah hati orang yang menerima Injil tersebut.

Perhatikan gambar berikut: Si pemberita membawa si penerima Injil kepada Allah melalui doa. Si pemberita mengadakan kontak dengan si penerima Injil. Dan si Pemberita mengandalkan Allah untuk berkarya terhadap si penerima Injil melalui doa.

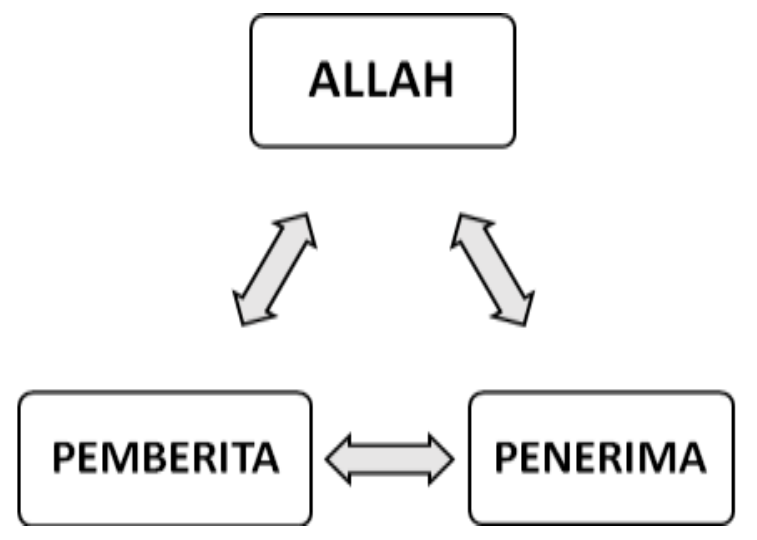

\section{b. Perkenalan dan Persahabatan}

Langkah awal sebelum penyajian Injil kepada pendengar, dimulai dengan PERTANYAAN TERBUKA. Pada tahap awal ini, sangat di tuntut keaktifan dari si pemberita Injil. Dalam tahap ini ada beberapa hal yang dapat kita tanyakan untuk mengakrabkan diri dengan sasaran yang sedang kita tuju. Kita boleh masuk menanyakan: asal dari mana, keluarga, situasi zaman sekarang ini, dll. Packer menegaskan bahwa, "penginjilan pribadi perlu dibangun di atas dasar persahabatan". Karena hal untuk berbicara dengan akrab tentang Tuhan Yesus Kristus harus diusahakan, dan anda mengusahakannya dengan caya meyakinkan orang yang anda ajak bicara bahwa anda adalah sahabatnya dan sungguh peduli kepadanya. ${ }^{9}$ Jadi, ketika

\footnotetext{
${ }^{9}$ J. I. Packer, Penginjilan dan Kedaulatan Allah, .....Hal. 67-68.
} 
seseorang ingin melakukan penginjilan pribadi maka perlu berdoa untuk meminta hikmat dari Tuhan untuk dapat mudah dekat dengan orang lain, khususnya orang yang tidak seiman dengan kita. Dalam kasus apapun, persahabatan sejati merupakan ciri utama dari seseorang yang sedang belajar mengasihi sesama seperti dirinya sendiri. Dan mengawali pembicaraan dalam rangka menjalin persahabatan, mulailah dengan pertanyaan-pertanyaan yang sederhana, seperti: mengajukan pertanyaan sebanyak-banyaknya untuk semakin mengenal lawan bicara.

Dan ajukanlah PERTANYAAN TERBUKA, untuk dapat mengenal orang yang kita harapkan dapat mendengar berita Injil. (Buatlah simulasi dengan temanmu, dan buatlah pertanyaan sebanyak-

banyaknya tentang dia!)

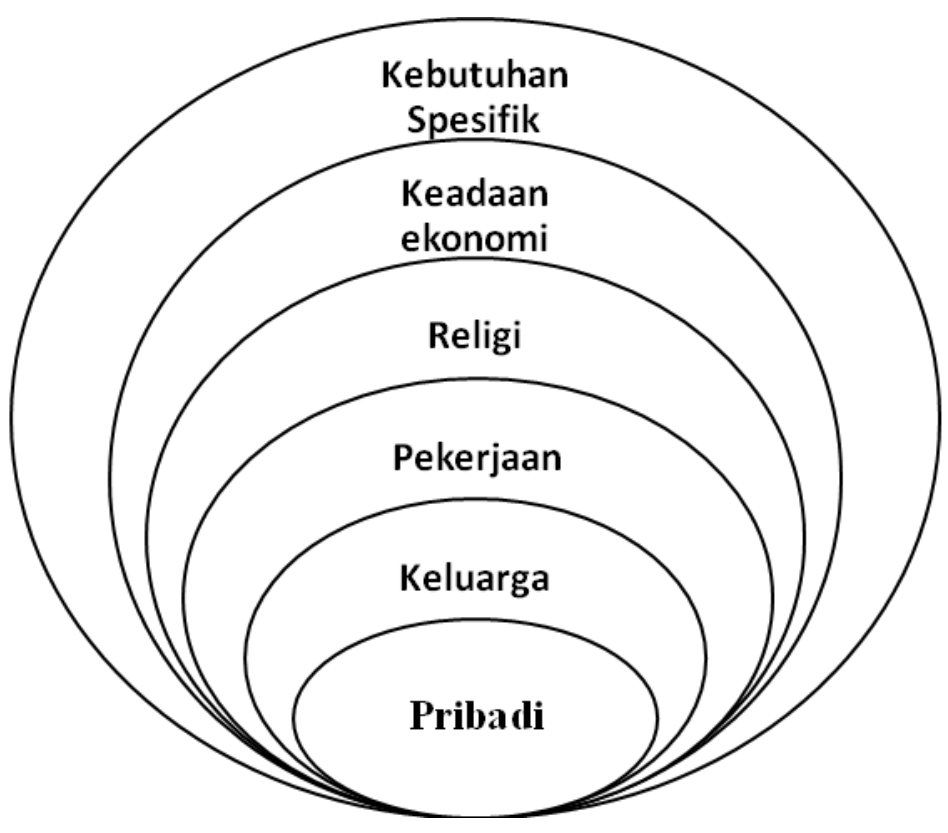

Arti gambar: mengajukan PERTANYAAN TERBUKA seputar kehidupan pribadi, keluarga, pekerjaan, religi, keadaan ekonomi, dan kebutuhan spesifik.

\section{c. Pengajuan Pertanyaan}

Setelah kita mengajukan PERTANYAAN TERBUKA untuk pengakraban maka lanjutkan dengan PERTANYAAN INTI yang membuka jalan untuk kita dapat menyampaikan pesan Injil, Pertanyaannya adalah: 
1. Seandainya hari ini Tuhan/Allah ada disini dan Dia PASTI menjawab doa anda, kira-kira apa yang ingin anda minta dari Dia?

$\checkmark \quad$ Jika jawaban tidak ada. Lanjutkan dengan: sekalipun sekarang ini anda tidak membutuhkan apa-apa, tetapi yang pasti semua manusia membutuhkan surga, bukan?

$\checkmark$ Jika jawaban, ada: harta, pasangan hidup, pekerjaan, dan lain-lain.

$\checkmark$ Maka lanjutkan pertanyaan kedua.

Memang, melalui jawaban nomor 2 sebenarnya bisa langsung dilanjutkan dengan mendoakan namun tetap kita harus dapat menguasai diri sehingga berita Injil dapat sampai secara utuh. Tetapi jika situasi tidak menginjinkan maka bisa langsung mendoakan dengan satu keyakinan bahwa kita disertai dengan tanda-tanda ajaib dari Tuhan (Mat. 10:1; 28:18-20; Mar. 16: 17-20).

2. Mengapa anda sangat membutuhkannya?

Berilah kesempatan kepada penerima berita untuk bisa menjelaskan alasannya, mengapa dia membutuhkan hal itu. Setelah itu lanjutkan pembicaraan dengan mengatakan: Tentu, semua orang membutuhkan seperti yang anda butuhkan sekarang ini. Tetapi kebutuhan yang sangat penting bagi semua orang yang ada di dunia ini, termasuk saya dan anda adalah berharap untuk masuk surga, bukan?

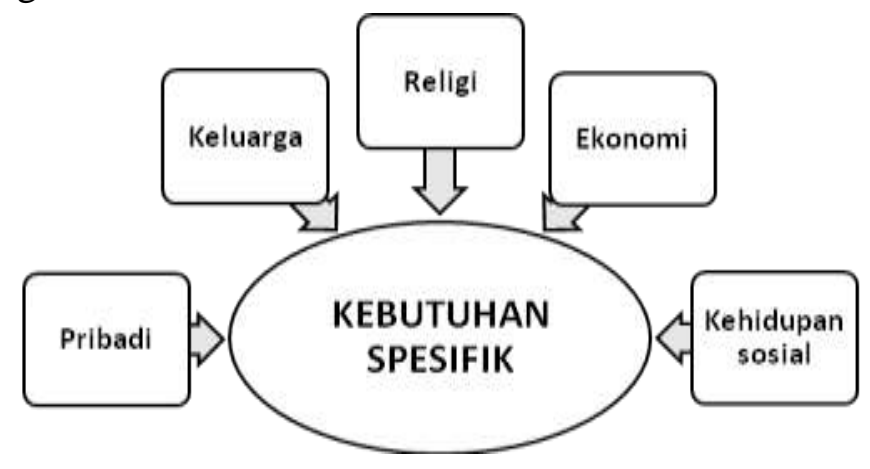

\section{Arti gambar: semua PERTANYAAN TERBUKA harus mengarah kepada PERTANYAAN INTI yang membongkar KEBUTUHAN SPESIFIK target.}

Setelah menjelaskan tentang kebutuhan spesifik target, maka lanjutkan dengan....

$\checkmark$ Memang, ada banyak orang yang berkata bahwa semua agama itu sama saja. Caranya menuju kesana yang berbeda-beda, bukan?

$\checkmark$ Bahkan ada yang berkata, banyak jalan menuju Roma. Tetapi apakah demikian kekristenan? 


\section{Kalimat PENGUNCI, BAGI KAMI ORANG KRISTEN SANGAT}

\section{BERBEDA.}

Tentu, perbedaan yang utama adalah bahwa kita dapat masuk surga bukan karena perbuatan baik, dalam artian berbuat baik sebanyak-banyaknya supaya bisa masuk surga, tetapi "perbuatan baik" relatif, bukan?

Misal: memberi uang kepada pengemis di perempatan lampu merah baik tidak? (itu menurut bapak)

Tapi bisa saja menurut orang lain, tidak baik/baik. Tetapi sebaik apa, tidak ada ukurannya bukan?

Namun bagi kami orang Kristen, justru ketika kita berdosa Tuhan datang mencari kita. Demikian juga yang dilakukanNya ketika Adam dan Hawa jatuh dalam dosa: "Adam-adam dimanakah engkau?

Tetapi persoalannya adalah, bagaimana cara masuk kesurga, sedangkan kita adalah manusia BERDOSA?

\section{Dasar-dasar Pemahaman Alkitab}

Untuk menguatkan pemberitaan yang penginjil sampaikan, maka ada beberapa pokok pemahaman Alkitab yang harus dimengerti dan disampaikan oleh penginjil kepada penerima.

\section{a. Pembahasan tentang Dosa}

Ketikamanusiapertamajatuhkedalamdosa, maka semua manusia termasuk saya dan anda sudah berdosa. Dosa menyebabkan hubungan antara Allah dengan manusia terputus, dan ketika manusia jatuh ke dalam dosa maka manusia menjadi musuh Allah. Menuru tanda apakah mungkin manusia yang berdosa masih bisa berhubungan dengan Allah sang pencipta yang kudus adanya?

Untuk memahami definisi dosa, perhatikan gambar berikut:

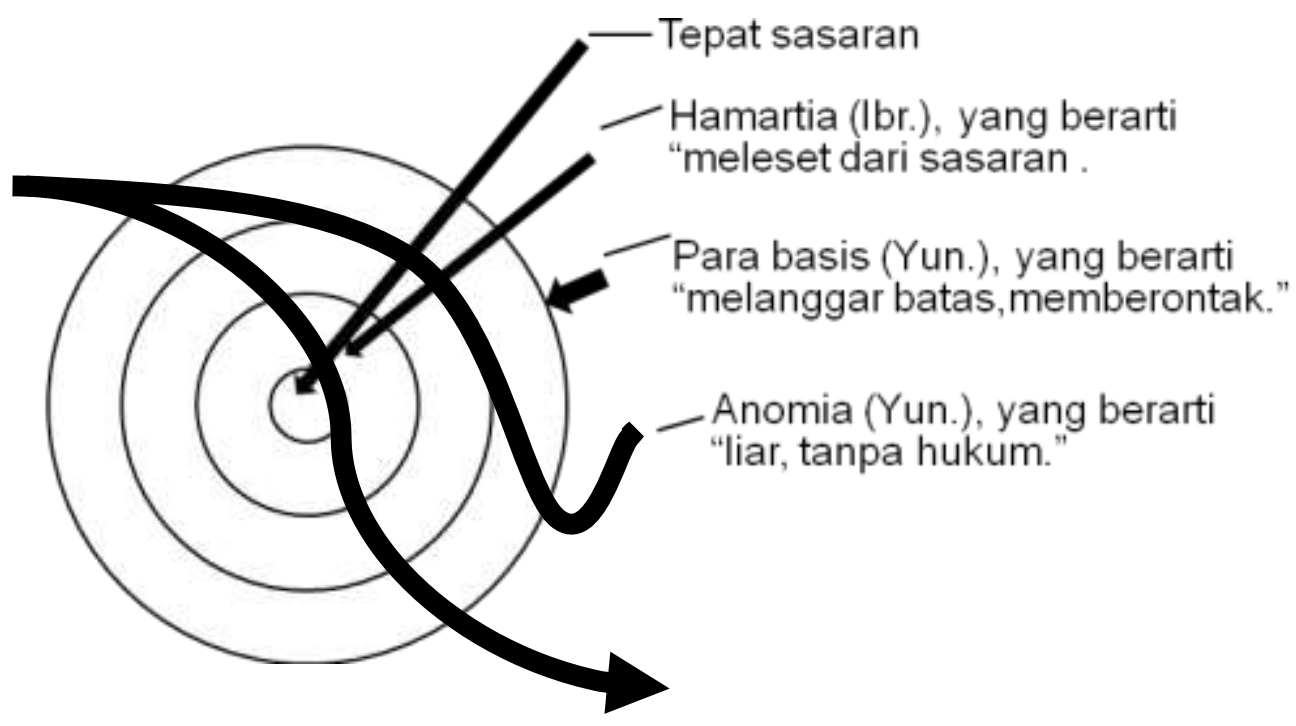




\section{b. Pembahasan tentang Agama}

Semua agama di dunia ini mengajarkan bahwa cara untuk mencapai surge tersebut adalah dengan memiliki moral yang baik dan melakukan kebaikan sebanyak-banyaknya. Usaha manusia untuk melakukan kebaikan dan memiliki moral yang baik, membuat manusia berharap pasti masuk surga. Tetapi jika melakukan kebaikan sebanyak-banyaknya, pertanyaannya sebanyak apa. Karena kebaikan itu relatif, misalnya: ketika kita member kepada pengemis, mungkin menurut pendapat kita hal itu adalah kebaikan tetapi menurut orang lain belum tentu hal itu dipandang sebagai baik. Karena bisa jadi hal itu akhirnya dianggap mengajari pengemis itu untuk malas bekerja dan sebagainya.

Bahkan ada juga yang mengatakan banyak jalan menuju Roma. Dalam arti semua agama itu sama saja, caranya saja yang berbeda-beda tetapi tujuannya sama. Apakah benar demikian? Dan apakah demikian kekristenan? BAGI KEPERCAYAAN KAMI BERBEDA..... Perhatikan perbedaan gambar berikut:

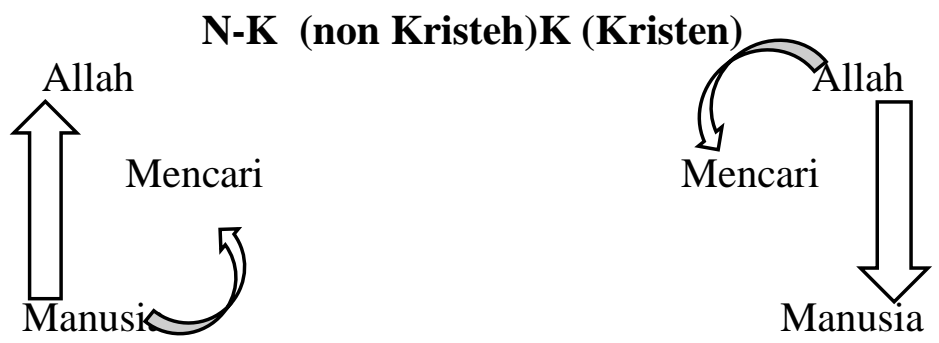

\section{c. Pembahasan tentang Allah}

Allah itu Maha Pengasih akan tetapi kita juga percaya Allah itu Maha Adil. Kalau Dia Allah yang adil pasti Dia akan menghukum orang berdosa akan tetapi karena Dia Allah yang Maha Kasih pasti Dia akan mengampuni orang berdosa. Bagaimana anda bisa memahami dan menjelaskan tentang dua sifat Allah ini dalam hubungan dengan kepastian kita masuk surga? Perhatikan gambar berikut:

1). Apakah Allahnya (i, h, b, h, a, dll) adalah Allahnya $K$ ?

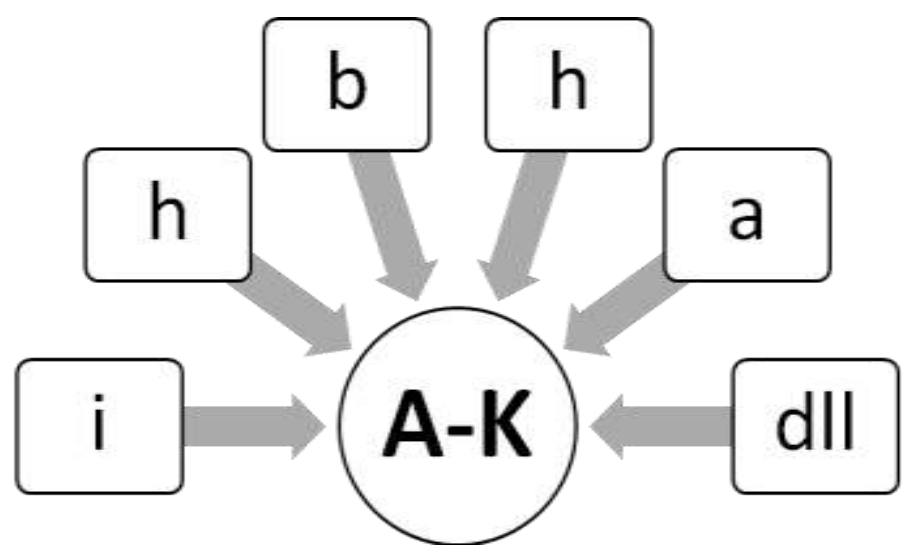


2). Apakah Allahnya (K) adalah Allahnya i, h, b, h, a, dll?

Perbedaannya adalah Allahnya orang Kristen adalah Allah yang berinisiatif untuk mencari manusia yang berdosa (Kejadian. 3:9 "dimanakah engkau?"). Sedangkan agama lain, Allah menunggu kedatangan umat-Nya bahkan dengan nilai kebaikan.

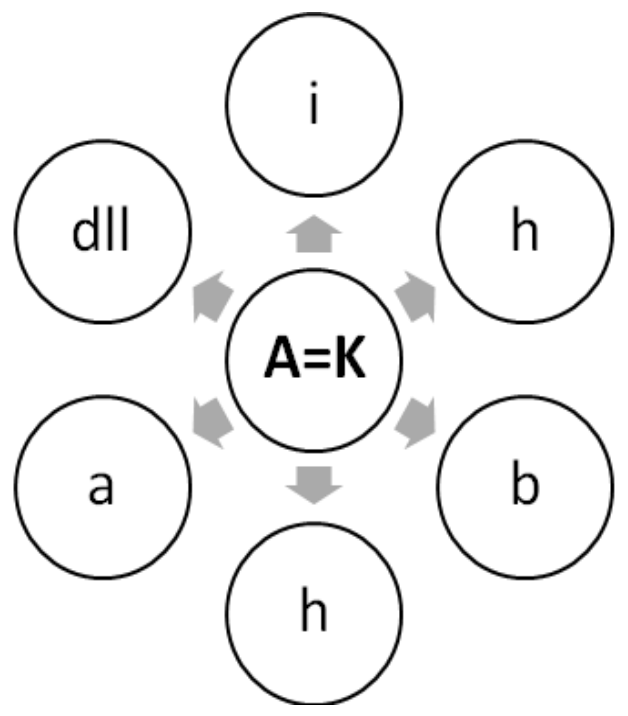

\section{d. Pembahasan tentang Yesus}

Allah yang adil akan menghukum orang berdosa dan semua orang telah berbuat dosa sehingga semua orang harus mendapatkan hukuman. Akan tetapi kasih Allah kepada manusia ciptaan-Nya membuat DIA mengutus Anak-Nya yang tunggal untuk menyelamatkan manusia. Yesus memungkinkan untuk bisa menyelamatkan manusia karena DIA Allah. Yesus Kristus datang ke dunia, sekalipun banyak orang yang menolak Dia. Tetapi Ia telah memberikan diriNya sebagai kurban penebusan salah antara Allah dengan manusia. Dia mati di kayu salib, padahal seharusnya kitalah yang disalib karena dosa dan pelanggaran kita. Tetapi Yesus menggantikan kita. Dan Yesus bangkit dari kematian membuktikan bahwa maut tidak berkuasa atas Dia. Yesus naik ke surge untuk menyediakan tempat bagi orang yang percaya kepada-Nya. Kalau begitu bagaimana caranya? 
Perhatikan gambar berikut:

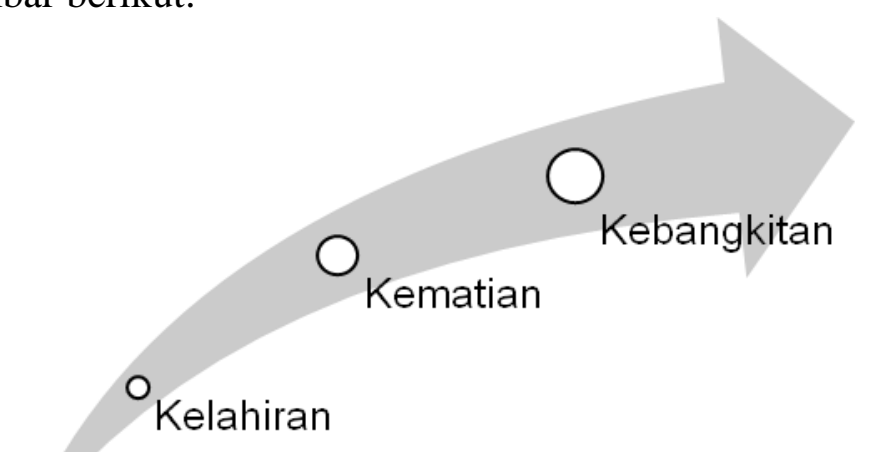

\section{e. Pembahasan tentang Iman}

Untuk bisa masuk ke surge tersebut hanya dengan percaya dan mengaku dengan mulut kita bahwa Yesus Kristus adalah Tuhan. Caranya dengan mengundang Yesus masuk ke dalam hati kita dan berkuasa secara penuh atas hidup kita. Dan tidak sulit untuk melakukannya, hanya dengan berdoa kepada Tuhan Yesus.

Metode ini tidak memaksa atau mengharuskan orang yang mendengar Injil untuk mengambil keputusan saat itu untuk menerima Yesus Kristus sebagai Tuhan dan Juruselamat. Karena tugas yang Tuhan percayakan untuk kita adalah memberitakan Injil. Dan pertobatan merupakan peran Roh Kudus dalam hidup setiap orang yang mendengar Injil. Namun, jika ada yang langsung merespon maka perlu dituntun untuk menerima Yesus dan mengudang Dia masuk dalam hati dan kehidupan pribadi.

Demikianlah keyakinan kami: Pilihan ada ditangan anda. Setelah semuanya selesai disampaikan, maka tawarkan untuk mendoakan kebutuhan hidup yang dari awal pembicaraan disampaikan.

\section{KESIMPULAN}

Pemahaman akan agama yang pluralis seringkali menjadi penghalang dalam penyajian Injil, karena pemahaman pluralisme berpikir bahwa semua agama sama saja, cuma caranya yang berbeda-beda. Para hamba Tuhan atau orang yang sedang menyajikan Injil dalam konteks pluralisme tersebut sering sekali kehabisan kata atau akal untuk memberikan penjelasan. Padahal peberitaan Injil tersebut harus tuntas dan clear. Pekabaran Injil merupakan 
tugas dan kewajiban orang-orang yang sudah mengaku menerima Yesus Kristus sebagai Tuhan dan Juruselamat. Namun faktanya, sekarang tidak sedikit orang Kristen atau yang "mengaku" Kristen dan Gereja menghindar dari pelayanan Pemberitaan Injil dengan berbagai alasan, seperti: Pemberitaan Injil itu tugas hamba-hamba Tuhan, cara memberitakan Injil jarang diajarkan, bahkan takut jika terjadi penolakan dari orang yang sedang dilayani. Karena itulah, Personal Evangelisation Methode diharapkan dapat menolong orang percaya, baik hamba Tuhan, jemaat awam untuk memberitakan Injil sehingga tidak mengalami benturan ataupun penolakan dari orang yang sedang dilayani. Personal Evangelisation Methode dapat menolong dalam perkenalan, bahkan dalam penyajian Injil.

\section{DAFTAR PUSTAKA}

2018 https://ms.wikipedia.org/wiki/Pluralisme_agama, di akses tanggal 27 Agustus.

Alwi Shihab,

Nd Islam Inklusif Menuju Sikap Terbuka.

Em Zul Pajri, Ratu Aprillia Senja,

2008 Kamus Lengkap Bahasa Indonesia, Jakarta: Difa Publisger.

George W. Peters

2006 (A Bilblical Theology Of Missions: Teologia Alkitabiah tentang Pekabaran Injil, Malang: Gandum Mas.

J. I. Packer,

2014 Penginjilan dan Kedaulatan Allah,Surabaya: Momentum.

Ngainun Naim dan Achmad Sauqi,

2008 Pendidikan Multikultural Konsep dan Aplikasi, Jogjakarta: ArRuzz Media.

Syamsul Ma'arif,

2005 Pendidikan Pluralisme di Indonesia, Jogjakarta: Logung Pustaka.

Yakub Tomatala,

2004 Penginjilan Masa Kini 1, Malang: Gandum Mas. 